\title{
Efficacy of different insecticides against pod borer Helicoverpa armigera in gram field
}

Munwar Ali Kandhro', Bhai Khan Solangi ${ }^{1 *}$, Mubeena Pathan ${ }^{2}$, Muhammad Akbar Lashari ${ }^{1}$, Muhammad Saleem Sarki ${ }^{3}$, Barkatullah Qureshi ${ }^{4}$, Velo Suthar ${ }^{4}$, Mitha Khan ${ }^{6}$ and Razzak Amin Shah ${ }^{5}$

1. Department of Entomology, Sindh Agriculture University, Tandojam-Pakistan

2. Information Technology Center, Sindh Agriculture University, Tandojam-Pakistan

3. Department of Soil Science, Sindh Agriculture University, Tandojam-Pakistan

4. Department of Statistics, Sindh Agriculture University, Tandojam-Pakistan

5. Department of English, Sindh Agriculture University, Tandojam-Pakistan

6. Entomologist DAR Fodder ARI Quetta Balochistan-Pakistan

*Corresponding author's email: bksolangi@gmail.com

Citation

Munwar Ali Kandhro, Bhai Khan Solangi, Mubeena Pathan, Muhammad Akbar Lashari, Muhammad Saleem Sarki, Barkatullah Qureshi, Velo Suthar, Mitha Khan and Razzak Amin Shah. Efficacy of different insecticides against pod borer Helicoverpa armigera in gram field. Pure and Applied Biology. Vol. 9, Issue 4, pp2397-2402. http://dx.doi.org/10.19045/bspab.2020.90254

Received: 03/04/2020

Revised: 27/06/2020

Accepted: 02/07/2020

Online First: 20/07/2020

\section{Abstract}

This study was carried out at Entomology Section, ARI, Tandojam on chickpea variety DG-92. Two applications were done to determine the efficacy of Match 050 EC, Polytrin-C 440 EC, Lorsban 40 EC insecticides at 15 days interval. The observation was recorded before treatment and after 24, 48, 72, 96 hours and 7 to 14 days. The pre-treatment count of the $H$. armigera in plot application with Match $(1.90 \pm 0.18)$ which was decreased to $1.33 \pm 0.19,1.00 \pm 0.30,0.73 \pm 0.12,0.67 \pm 0.13,0.70 \pm 0.13$ and $0.40 \pm 0.09 /$ plant, respectively; followed by the plot application with Polytrin-C the $H$. armigera

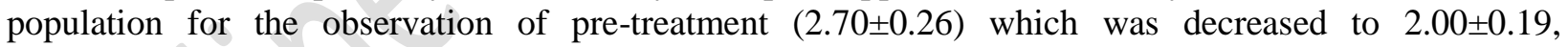
$1.70 \pm 0.19,1.53 \pm 0.17,1.07 \pm 0.17,1.03 \pm 0.21$ and $0.40 \pm 0.09$ /plant after $24,48,72,96$, one and two week of application, respectively. in the same way, on the plot application with Lorsban, the pre-treatment pod borer population was $(3.17 \pm 0.21)$ reduced to $2.73 \pm 0.19,2.37 \pm 0.19,2.07 \pm 0.18,1.93 \pm 0.30,1.70 \pm 0.22$ and $1.50 \pm 0.24 /$ plant after $24,48,72,96,1$ week and 2 weeks of application, respectively. In case of untreated control plots, the population of the $H$. armigera remained frequently high all through the study period which was $3.77 \pm 0.45$ before treatment, $3.97 \pm 0.42,4.00 \pm 0.54,4.20 \pm 0.67,4.23 \pm 0.51,4.80 \pm 0.62$ and $5.30 \pm 0.43 /$ plant after 24, 48, 72, 96 hours , 1 week and 2 weeks of application, respectively. The second application results showed that the $H$. armigera population varied significantly $(\mathrm{P}<0.05)$ when observed after 24, 48, 72, 96, one and two week after of application; while pre-treatment population on the experimental units was almost uniform and non-significant $(\mathrm{P}>0.05)$ After second application the population of $H$. armigera before treatment with Match was $(2.00 \pm 0.17)$ declined to $1.60 \pm 0.18$, $0.97 \pm 0.13,0.83 \pm 0.13,0.70 \pm 0.13,0.57 \pm 0.10$ and $0.23 \pm 0.08$ /plant.

Keywords: Insecticides, Pod borer, H. armigera Chickpea, Cicer arietinum 


\section{Introduction}

Chickpea (Cicer arietinum L.) which is essential legume crop It was documented that this was almost being sown since over 7000 years. It is cultivated as staple and cash crop on little to huge areas and its immature seeds, shoots and pods also being utilized as a vegetable [1]. Due to its nutritional values especially its seed which is highly enriched with protein (25.3-28.9\%); considered as a most important human consumed food [2]. In field, Helicoverpa armigera is a serious insect pest which is damage grains and responsible to cause economical loss to chickpea production. Beside chickpea, it is also attacks on cabbage, tomato, maize, peanuts, tobacco, cotton and other pulses. Adult female lays singly 300-500 eggs on host plants. Eggs are yellowish, shiny and lay singly on whole plant parts. The incubation period of eggs approximately two to five days and new emerge larvae infest to pods, it is reported that a caterpillar is capable to infest 40 pods. The length of larva is $40 \mathrm{~mm}$ long and hairy in appearance with different colors and for pupation the larvae drops to the ground. The adults of $H$. armigera are about 14 to 18 $\mathrm{mm}$ in its body length and $30-36 \mathrm{~mm}$ in its wing expanse. The hind wings are lighter and whitish in color. The forewings are marked with black spots of varying size on upper side and grayish wavy lines. One complete generation may takes 30-37 days in favorable conditions. There are total five to seven generations in a season [3]. H. armigera is considered as major pest of chickpea crop which cause heavy economic losses by reducing quality and quantity of production [4].

Various types of chemicals have been reported to be effective in against this particular pest of chickpea in the field. For the management of $H$. armigera, its Economic Injury Levels (EIL) were repoted as 0.92 and 0.90 larvae/meter row under irrigated and arid regions, respectively [5].
The application of synthetic insecticides should only be done when pest population crossed the economic threshold level (ETL). Most of the insecticides are belonging to organophosphates, carbamates and synthetic pyrethroids etc. Their indiscriminate use has created number of well known problems [6]. Insecticidal resistance in pests has often been a problem and it is only one of the most valuable reasons why insecticides with a new mode of action have been needed [7]. The chemical insecticides can be reduced the loss which caused by $H$. armigera [8]. During the pod formation stage, the infestation of $H$. armigera increased greatly $[8,9]$. Owing to the application of insecticides has resulted in many problems such as emergence of new pests, minor pests becoming major pests, increase in the insect resistance to insecticides and pesticide contamination in the environment. Hence, it is necessary to assess the lethal potential of new chemicals against the target species. Many synthetic insecticides namely Match, Larsbean, Profenophose, Chloropyriphose, Flubendiamide, Chlorantraniliprole, Indoxacarb and Proclaim have been found powerfull for controlling $H$. armigera [10]. Therefore, this study was conducted to observe the efficacy of different insecticides which can be used to control $H$. armigera in gram field.

\section{Materials and methods}

This experiment was conducted during 2017-18 at Entomology Section, Agriculture Research Institute, Tandojam with plot size $\left(9350 \mathrm{ft}^{2}\right)$ for this purpose variety of DG-92, was sown on 17-11-2017. It was designed through complete randomized block design with three replication of each treatment. Before application of insecticides calibration was done by application the plot with water for calibrate water requirements coverage plants. Three treatments with control were used to evaluate the efficacy of insecticides to compare with control. The insecticides 
namely Match 050 EC, Polytrin-C 440 EC, Lorsban $40 \mathrm{EC}$, and control (untreated) was used. The observation was taken before treatment and after treatment on 24 hours, 48 hours, 72 hours, 96 hours and after 1 week and two week. 16 litter application tank. The second application was done after two week observation with same methodology. The observation was taken randomly from ten plants/replication of each treatment. After harvesting the crop yield data in insecticide treated plots as well as control plots was also recorded. The recorded data was calculated with analysis of variance (ANOVA) and Least Significant Difference.

\section{Results}

\section{Population fluctuation of $\boldsymbol{H}$. armigera after first application}

After application of first application the population of $H$. armigera distressed by planned insecticides was statistically analyzed and described the analysis of variance. It was observed that variation in inhabitants after application of initial dose of synthetic insecticides were non-significant for pre-treatment count and significant for H. armigera population after $24,48,72$ and 96 hours, and one week and two weeks of application.

Population of $H$. armigera on experimental plot shown in (Table 1) that after 24 hours, 48 hours, 72 hours, 96 hours, 1 week and 2 week of application, the pre-treatment population on plot treated with Match $(1.90 \pm 0.18)$ which was decreased to $1.33 \pm 0.19,1.00 \pm 0.30,0.73 \pm 0.12,0.67 \pm 0.13$, $0.70 \pm 0.13$ and $0.40 \pm 0.09 /$ plant, respectively; followed by the plot application with Polytrin-C the pest population of pretreatment $(2.70 \pm 0.26)$ which was decreased to $2.00 \pm 0.19, \quad 1.70 \pm 19, \quad 1.53 \pm 0.17$, $1.07 \pm 0.17,1.03 \pm 0.21$ and $0.97 \pm 0.24 /$ plant after 24 hours, 48 hours, 72 hours, 96 hours, 1 week and 2 weeks of application, respectively. Similarly, plot application with
Lorsban, the pre-treatment population of pod borer $(3.07 \pm 0.22)$ which was decreased to $2.40 \pm 0.20,2.10 \pm 0.19,2.07 \pm 0.17,1.57 \pm 0.21$, $1.47 \pm 0.18$ and $1.17 \pm 0.10 /$ plant after 24 hours, 48 hours, 72 hours, 96 hours, 1 week and 2 weeks of application, respectively. In control plots, a rise trend in population of the $H$. armigera was recorded throughout the experiment which was $3.83 \pm 0.48$ before treatment, $4.00 \pm 0.40,4.20 \pm 0.52,4.23 \pm 0.45$, $4.37 \pm 0.43 \quad 4.43 \pm 0.48$ and $5.13 \pm 0.40 /$ plant after 24 hours, 48 hours, 72 hours, 96 hours, 1 week and 2 weeks of application, respectively. It was observed that all the insecticides were having good results to minimize pest population below the economy injury level but their effectiveness was decreased as application time increasing manner as the population after 15 days reached at economic injury level. On the basis of effect of insecticides on $H$. armigera population, the insecticides were ranked as Match > Polytrin-C > Lorsban.

\section{Population fluctuation of $H$. armigera after second application}

The results of the second application as the population of $H$. armigera distressed by different insecticides was analyzed statistically and the analysis of variance confirmed that the differences in population after second application of synthetic insecticides were non-significant for before treatment count and significant for population after 24, 48, 72 and 96 hours, and 7 and 15 days of application.

The population of pod borer after 24 hours, 48 hours, 72 hours, 96 hours, 1 week and 2 weeks of application shown in (Table 2) that the pre-treatment pest population treated with Match was $(2.00 \pm 0.17)$ declined to $1.60 \pm 0.18,0.97 \pm 0.13,0.83 \pm 0.13,0.70 \pm 0.13$, $0.57 \pm 0.10$ and $0.23 \pm 0.08 /$ plant, respectively; followed by the plot application with Polytrin-C whereas the pre-treatment pest population $(2.80 \pm 0.24)$ decreased to 2.57. $\pm 0.25, \quad 2.07 \pm 0.24, \quad 1.90 \pm 0.26$, 
$1.67 \pm 0.26, \quad 1.53 \pm 0.27$ and $1.27 \pm 0.22 /$ plant after $24,48,72,96$ hours, 1 week and 2 weeks of application, respectively. Similarly, on the plot applicationed with Lorsban, the pre-treatment pest population was $(3.17 \pm 0.21)$ reduced to $2.73 \pm 0.19$, $2.37 \pm 0.19,2.07 \pm 0.18,1.93 \pm 0.30,1.70 \pm 0.22$ and $1.50 \pm 0.24$ /plant after 24 hours, 48 hours, 72 hours, 96 hours, 1 week and 2 weeks of application, respectively.

Table 1. Population fluctuation of Helicoverpa armigera after $1^{\text {st }}$ application of different insecticides

\begin{tabular}{|c|c|c|c|c|c|c|c|}
\hline \multirow[b]{2}{*}{ Treatments } & \multirow{2}{*}{$\begin{array}{c}\text { Pre- } \\
\text { treatment }\end{array}$} & \multicolumn{6}{|c|}{ Time after treatment } \\
\hline & & 24 hours & 48 hours & 72 hours & 96 hours & 1 week & 2 week \\
\hline Match & $1.90 \pm 0.18 \mathrm{c}$ & $1.33 \pm 0.19 \mathrm{c}$ & $1.00 \pm 0.30 \mathrm{c}$ & $0.73 \pm 0.12 c$ & $0.67 \pm 0.13 c$ & $0.70 \pm 0.13 c$ & $0.40 \pm 0.09 \mathrm{c}$ \\
\hline Polytrin-C & $2.70 \pm 0.26 b c$ & $2.00 \pm 0.19 b c$ & $1.70 \pm 0.19 b c$ & $1.53 \pm 0.17 \mathrm{~b}$ & $1.07 \pm 0.17 \mathrm{bc}$ & $1.03 \pm 0.21 \mathrm{~b}$ & $0.97 \pm 0.24 \mathrm{bc}$ \\
\hline Lorsban & $3.07 \pm 0.22 \mathrm{ab}$ & $2.40 \pm 0.20 \mathrm{~b}$ & $2.10 \pm 0.19 \mathrm{~b}$ & $2.07 \pm 0.17 \mathrm{~b}$ & $1.57 \pm 0.21 \mathrm{~b}$ & $1.47 \pm 0.18 \mathrm{~b}$ & $1.17 \pm 0.10 \mathrm{~b}$ \\
\hline Control & $3.83 \pm 0.48 \mathrm{a}$ & $4.00 \pm 0.40 \mathrm{a}$ & $4.20 \pm 0.52 \mathrm{a}$ & $4.23 \pm 0.45 \mathrm{a}$ & $4.37 \pm 0.43 \mathrm{a}$ & $4.43 \pm 0.48 \mathrm{a}$ & $5.13 \pm 0.40 \mathrm{a}$ \\
\hline LSD & 1.3348 & 2.9727 & 2.0374 & 1.1212 & 1.2214 & 0.7894 & 0.8435 \\
\hline
\end{tabular}

Table 2. Population fluctuation of Helicoverpa armigera after $2^{\text {nd }}$ application of different insecticides

\begin{tabular}{|c|c|c|c|c|c|c|c|}
\hline \multirow{2}{*}{ Treatments } & \multirow{2}{*}{$\begin{array}{c}\text { Pre- } \\
\text { treatment }\end{array}$} & & \multicolumn{5}{|c|}{ Time after treatment } \\
\hline & & 24 hours & 48 hours & 72 hours & 96 hours & 1 week & 2 week \\
\hline Match & $2.00 \pm 0.17 \mathrm{c}$ & $1.60 \pm 0.18 \mathrm{c}$ & $0.97 \pm 0.13 c$ & $0.83 \pm 0.13 c$ & $0.70 \pm 0.13 \mathrm{c}$ & $0.57 \pm 0.10 \mathrm{c}$ & $0.23 \pm 0.08 \mathrm{c}$ \\
\hline Polytrin-C & $2.80 \pm 0.24 b c$ & $2.57 \pm 0.25 b$ & $2.07 \pm 0.24 b$ & $1.90 \pm 0.26 \mathrm{~b}$ & $1.67 \pm 0.26 \mathrm{~b}$ & $1.53 \pm 0.27 \mathrm{bc}$ & $1.27 \pm 0.22 b$ \\
\hline Lorsban & $3.17 \pm 0.21 \mathrm{ab}$ & $2.73 \pm 0.19 b$ & $2.37 \pm 0.19 \mathrm{~b}$ & $2.07 \pm 0.18 b$ & $1.93 \pm 0.30 \mathrm{~b}$ & $1.70 \pm 0.22 \mathrm{~b}$ & $1.50 \pm 0.24 \mathrm{~b}$ \\
\hline Control & $3.77 \pm 0.45 a$ & $3.97 \pm 0.42 \mathrm{a}$ & $4.00 \pm 0.54 \mathrm{a}$ & $4.20 \pm 0.67 \mathrm{a}$ & $4.23 \pm 0.51 \mathrm{a}$ & $4.80 \pm 0.62 \mathrm{a}$ & $5.30 \pm 0.43 a$ \\
\hline LSD & 1.3384 & 2.9908 & 2.2257 & 1.5334 & 1.8432 & 1.0978 & 1.1023 \\
\hline
\end{tabular}

In order to untreated control plots, the population of H.armigera stayed persistently high all through the study period which was $3.77 \pm 0.45$ before treatment, $3.97 \pm 0.42$, $4.00 \pm 0.54,4.20 \pm 0.67,4.23 \pm 0.51,4.80 \pm 0.62$ and $5.30 \pm 0.43 /$ plant after 24 hours, 48 hours, 72 hours, 96 hours, 1 week and 2 weeks of application, respectively. The observations of the second application of various insecticides also specify that all applied insecticides examined in this study against $H$. armigera were capable to manage $H$. armigera. In the light of decrease of insect pest population observation after 15 days of the application, the status of insecticide stayed same as observed at the time of first application as Match > PolytrinC > Lorsban.

Yield of gram crop treated with different insecticides

The (Fig.1) indicates that crop yield was recorded as 20,17, 15 and 10 munds/acre in plots treated with Match, Polytrin-C, Lorsban and Control, respectively. Maximum crop yield was observed in plot which was treated with match and minimum crop yield was observed in control plot. 


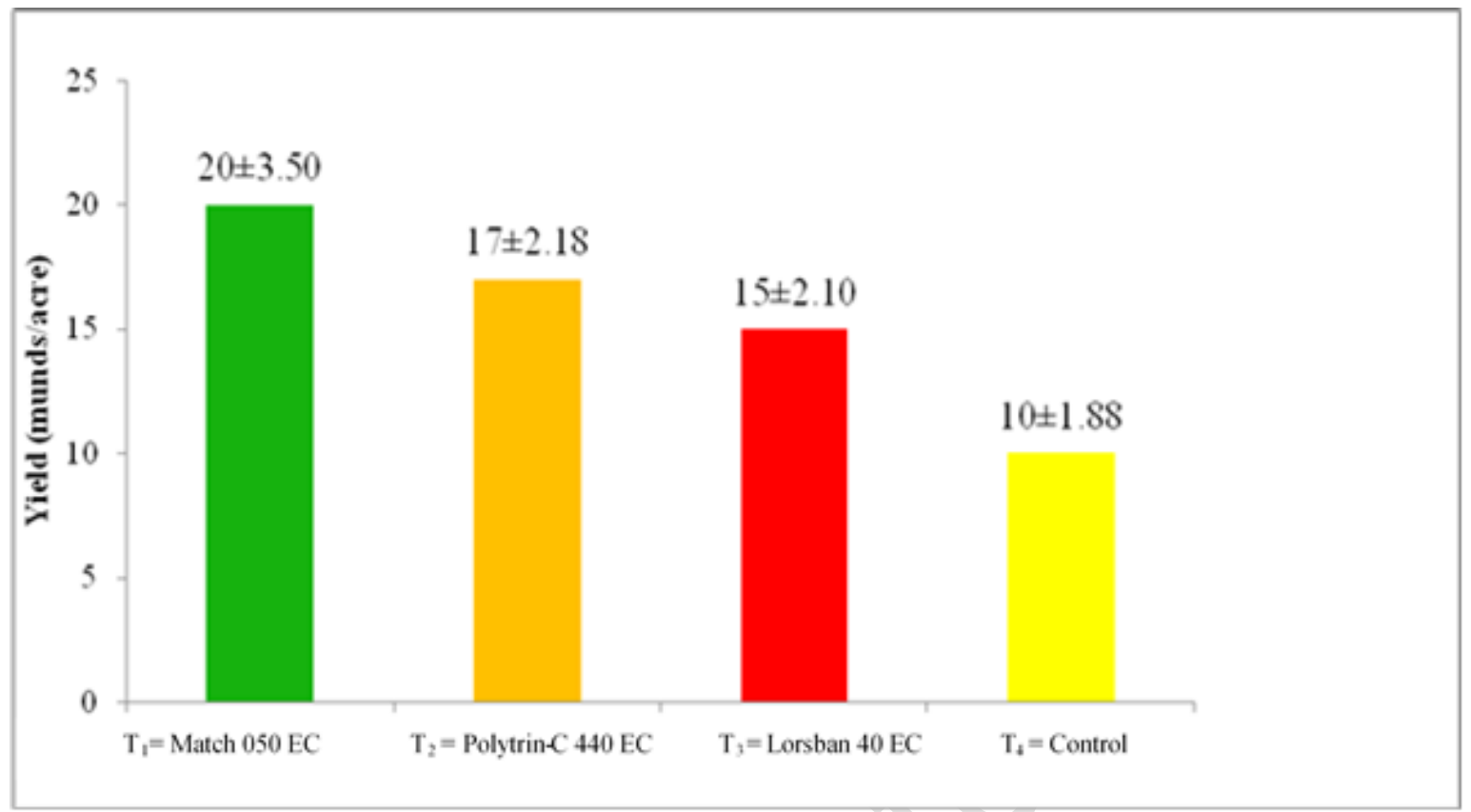

Figure 1. Yield munds/acre

\section{Discussion}

All the synthetic tested insecticides were capable against pod borer population and their capability was well determined even 15 days after application as the pest population after two weeks was under control. This study showed that after two weeks the efficacy of synthetic insecticides against $H$. armigera population in relationship with pre-treatment count showed that Match was observed as highest efficacy $0.40 \pm 0.09$ /plant after first application and $0.23 \pm 0.08$ /plant after second; while Polytrin-C ranked second with first application efficacy mean $0.97 \pm 0.24 /$ plant and $1.27 \pm 0.22 /$ plant after second application. Similarly, Lorsban showed highest efficacy mean $1.17 \pm 0.10 /$ plant and $1.50 \pm 0.24 /$ plant after first and second application. In the light of pest population decline after 15 days of application, the insecticides were ranked as Match > Polytrin-C > Lorsban. Furthermore, the maximum production was observed in Match treated plots followed by Polytrin-C, Lorsban and control plots, respectively. The observations of the current study are in accordance with various past scientists who have reported their study results comparable perspectives. Sreekanth et al. [11] reported that acetamiprid, fipronil and thiamethoxam insecticides could be applied against $H$. armigera and also higher yield was achieved. Shah et al. [12] confirmed the potential of Chlorpyrifos $40 \mathrm{EC}$, Match 50 EC, Lambdacyhalothrin $2.5 \mathrm{EC}$, endosulfan $35 \mathrm{EC}$ and cypermethrin $10 \mathrm{EC}$ insecticides that reduced the damage rate of $H$. armigera and also higher yield obtained from insecticide treated plots when evaluated to control. A experiment was reported by Javaid et al. [13] and results revealed that Profenofos and Coragen reduced $85 \%$ and $90 \%$ infestation in pigeon pea field and remain effective even after 7 days 0 application. Thus, these insecticides confirmed potential against $H$. armigera with high grain yield. Therefore, in continuation of the many previous research works, this study also confirmed the potential of Match, Poytrin-C and Lorsban 
insecticides to protect chickpea crop from $H$. armiger. However, Match was proved as having more effective properties against $H$. armigera in chickpea field followed by Polytrin-C and higher yield was also obtained from Match insecticide applicationed plots.

\section{Conclusion}

It was concluded that all the applied synthetic insecticides were found effective against $H$. armigera even population was controlled after two weeks of application. Match insecticide was only found to be the most powerful among all three insecticides applied. In the light of pest population decline after 15 days of the application, the pesticides were ranked as Match > Polytrin$\mathrm{C}>$ Lorsban.

\section{Authors' contributions}

Conceived and designed the experiments: MA Kandhro, BK Solangi, MA Lashari \& MS Sarki, Performed the experiments: MA Kandhro, RA Shah \& BK Solangi, Analyzed the data: V Suthar, M Khan, M Pathan \& B Qureshi, Contributed materials/ analysis/ tools: MA Kandhro, MS Sarki, BK Solangi \& MA Lashari, Wrote the paper: MA Kandho, BK Solangi \& M Pathan.

\section{References}

1. Weber et al. (2011). Effect of selected insecticides on Helicoverpa armigera (Hubner) (Lepidoptera: Noctuidae) on tomato (Lycopersicon esculentum Miller) and their successful management. $A d v$ in Entomol 3(1): 16-23.

2. Sherestha et al. (2015). Comparative efficacy of various insecticides to control gram pod borer (Helicoverpa armigera Hubner) on chickpea. Asian $J$ of Plant Sci 2(2): 403-405.

3. Malik (2014). Efficacy of various nonchemical methods against pulse beetle, Callosobruchus maculatus (F.). ENDURE International conference, Diversifying Crop Protection, October, 12-15, France.
4. Khare \& Ujagir (2014). Duration developmental stages of Callosobruchus (Coleoptera: Bruchidae) on Azuki bean and the effects of neem and sesame oils at different stages of their development. Pak $J$ of Biol Sci 6(1): 332-335.

5. Prabhakar et al. (2015). Criterion for the selection of high yielding genotypes and pure lines of chickpea. Pak $J$ of Agric Res 12(4): 90-94.

6. Dhingara S, Kodandaram MH, Hedge RS \& Srivastava C (2013). Evaluation of different insecticides mixture against third instars larvae of Helicoverpa armigera Hub. Ann J of Plant Prot Sci 11(2): 274-276.

7. Masanori et al. (2015). Field efficacy of chemical pesticides against Maruca vitrata Fabricius (Lepidoptera: Crambidae) infesting gram in Brazil. American $J$ of Plant Sci 6(1): 537-544.

8. Balasubramanian G, Babu PCS \& Manjula TR (2013). Efficacy of Spicturin against Helicoverpa armigera Hubner on chickpea (Cicer arietinum L.). Madras Agric J 88(2): 336-338.

9. Jadhav RS \& Suryawanshi DS (2013). Chemical control of Helicoverpa armigera (Hubner) on chickpea. J of Maharashtra Agric Uni 23(1): 83-84.

10. Sahito HA, Lund MA, Bukhari SA, Talpur MA \& Mastoi AH (2013). Efficacy of different insecticides against Helicoverpa armigera (Hubner) on tomato crop. Inter $J$ of Med and Appl Sci 12(3): 62-76.

11. Sreekanth et al. (2011). Field efficacy of different insecticides against Helicoverpa armigera (Hubner) infesting chickpea. $J$ of Legume Res 33(4): 269-273.

12. Shah et al. (2013. Relative efficacy of newer insecticides and biopesticides against Helicoverpa armigera (Hubner) in chickpea. J of Entomol and Zool Stu 15(3): 455-462.

13. Javaid I, Farooq SU, Jamil M \& Muhammad Y (2015). Relative efficacy of selective insecticides against gram pod borer (Helicoverpa armigera $\mathrm{H}$.) of chickpea. $J$ of Entomol 51(2): 355-369. 